\title{
Consistency Between Political Party's Program and Policy Product in Bandung Regency
}

\author{
${ }^{1}$ DEDE SRI KARTINI, ${ }^{2}$ NENENG YANI YUNINGSIH, ${ }^{3}$ IYEP SAEFULRAHMAN \\ 1,2,3 Program Studi Ilmu Pemerintahan FISIP, UNPAD, Jalan Raya Bandung-Sumedang Km 21 Jatinangor \\ email: ${ }^{1}$ dedekartini@yahoo.com; ${ }^{2}$ nenengyany@yahoo.co.id; ${ }^{3}$ sef73rahman@gmail.com
}

\begin{abstract}
After political parties win election, several political issues will be formulated into a series of alternative policy. Based on this system, political parties have a role to collect the will of society and then use it as consideration to make various public policies. Vision and mission of Golkar as the winner of 2010 elections, has become vision and mission of all SKPD even the village chief. The realization of the programs when Golkar's candidate used rural development policy product as source of campaign in 2010-2015 local elections for Bandung Regent, have been consistent. In the other side, the obstacles are human resources in rural areas which frequently changed when trained by BPMPD, late disbursement in rural development and grants for Uninhabitable Houses (Rumah Tidak Layak Huni) are insufficient and not equally distributed. Moreover, the policy has been already consistent between Golkar's programs with the product of public policy, particularly in the field of rural development. If the government is able to cover up weaknesses in the implementation of rural development programs, it should fulfill the needs of rural communities for employments on dry season as priority program for the followings years. Based on this research, it can be concluded that, in the micro policy level, the policies face a distortion because of the mismatch between the tasks and functions BPMPD in reality.
\end{abstract}

Keyword: Public Policy, Political Party, Program, Rural Development

\section{Introduction}

In order to observe the conformity which has been presented by the candidates on campaign period with the reality when one of them won the election, Klinaemann et. al (2001) used "congruent" as well as Putra (2003) which stated in book namely "Political Party and Public Policy: Analysis of Congruency Party Political Pledge with Public Product Policy Realization in Indonesia 19992003 ". However, researchers do not use the term congruency because it is incompatible with research using a qualitative approach. By using a quantitative approach, Klinaemann et al. created a statistical equation to see the congruence, while Putra used a qualitative approach. Therefore, researchers use the term "consistency" which is used by Robertson (Klinaemann et al. 2000) to see the suitability between campaign promises of political promiscuity and the policies made by electoral winners."
If a leader wants to obtain the power to govern, according to Law No. 32 of 2004 on Regional Government, the previous election of Regional Leader originally was elected by the DPRD (Regional Representative Council), but it turned into local election (Pilkada) which directly chosen by people (Pratikno, 2009). These changes have led to a shift in public policy making, since previously it was a purely political decision-making in electoral super-structure without society involvement, but only the Regional Leader and the DPRD. But now, as the local elections mechanism is established, society's access to decisionmaking processes which is closely related to their interests is expanded (Hikmat, 2014: 01).

According to Home Ministry Regulation No. 54/2010 on Implementation of Government Regulation No. 8/2008 Concerning Stages, Procedures for Formulating, Controlling, and Evaluating the Implementation of Regional

Received: April 06, 2016, Revision: August 22, 2017, Accepted: December 18, 2017

Print ISSN: 0215-8175; Online ISSN: 2303-2499. DOI: http://dx.doi.org/10.29313/mimbar.v33i2.2330.269-276

Accredited B based on the decree No.040/P/2014, valid on February, 18, 2014 until February, 18, 2019. Indexed by DOAJ, Sinta, IPI 
Development Plans, development plan is description of several agendas offered by Regional Leader during his political campaign turns into Medium Term Development Plan/ RPJMD (Rencana Pembangunan Jangka Menengah Daerah). Therefore, RPMD is contained with Regional Leader visionmission, which is also identical visions and missions of political parties.

Through the campaigns, candidates from political parties explained their programs which will be formulated into policies when they had been elected. The potential programs, which will be transformed into policies, are called promise of campaign. According to Robertson, promise of campaign should be implemented consistently by the elected candidates, in order to gain public trust in political parties (Klinaemann,et.al ., 2000: 43).

Klinaemann et.al research was relied upon structural functionalist framework which positioned political parties as institutions which play two important roles in ensuring the well-being of democratic regimes:

\begin{abstract}
"First, political parties selected and compiled various discourses and presented it to the voters inside a consequence package, as being reflected on parties platform/manifesto. Second, the winner parties positioned themselves as the backbone of the elected government with common premise that their promise of campaign will be reinstated as public policy" (Klinaemann, et al., 2000: xv).
\end{abstract}

Based on those political parties' roles, the research would like to observe the correlation between Golkar's program as winner party in Bandung Regency election in 2010 and public policy product in rural development designed by its candidates: Dadang Naser dan Deden Rukman Rumaji from 2011-2015.

The research focuses on the 6 th mission, as it is the prominent program of Bandung Regency Regent in 2010-2015 periods. In addition, the focus of development is generally in the villages, thus the success of village development will affect other programs.

Furthermore, the research is important because no other institution is concerned with policy's achievements which are produced by the campaign promise. Nevertheless, the actual competitive election lies on society's ability to choose a candidate who can implement their role well in the government democratically (Powell, 2010). Thus, the party must realize the campaigns promise or party programs which is presented by their candidates and transform it into public policy products, when the candidates gain power. Hopefully, this research will give good contribution both practically and theoretically. Practically, it is public who is able to examine the election's winner whether they are able to fulfill their promise or not. Towards the development of Governmental Science, hopefully, it will give actual input on the formation of government through election and explain certain way on how we should monitor the running government, which one of them can be achieved through consistency between party program and its output policy.

\section{Research Methods}

The research used descriptive method with case study type, and qualitative approach. Descriptive method "is designed to collect information about the current state of affairs (while in progress)" (Sevilla, et al., 1993: 71). Creswell (2012: 20), who quotes on Stake's argument (1995) and mentions that case study is one of the strategies in qualitative research.

According to Denzin and Lincoln (2011: 11) qualitative words are difficult to measure, but this study emphasizes the nature of the social reality built up closely between the researchers and the subjects, and situational constraints which formed the research. In order to observe the reality, researchers will be positioned themselves directly into the research setting, and held interview with the informants to collect the data. The data will then be selected or reduced to determine whether it will be used in the analysis or being discarded. Afterwards, the data will be interpreted to answer the research question. In this stage, a new finding is expected to be produced, i.e., whether we find consistency in the winning political party program or not.

As stated by Marshall dan Rossman (1995: 78), the elementary methods in collecting information in qualitative research are (1) participation in the setting; (2) direct observation; (3) in-depth interviewing; and (4) document review. Therefore, for this research, the researcher will only use the third and fourth methods. In-depth interviewing is described by Kahn and Cannell as "a conversation with a purpose."

How is the consistency between political party program of Golkar and village development policy products in Bandung 
Regency?

\section{Literature Review}

Russell J. Dalton and Martin P. Wattenberg (2000) had been extracted the thought of V.O Key (1964) about a part of political parties framework. They stated that political parties possessed a function in government, (Pamungkas 2011). In this context, political parties play a role in managing and creating discourse which structuring problems in the government. They had been identified with several fundamental functions in democratic process. There are seven main functions of political parties in the government.

First, they create majority in government. This function is implemented after the election. The parties which successfully gain vote in parliament are obliged to create politic of majority in the parliamentary system, and then establishing a government. In the other side, while a presidential system is used, they had to ensure the effectiveness of government. If there is no absolute majority in the parliament, the coalition among parties is impossible. The key in forming coalition formation to establish a government is the distribution of parties' political resources and position.

Second, the parties' function is to organize the government. In this function, political parties provide mechanism to organize various interests and make sure the cooperation of each individual legislator. In the parliament, the parties should be responsible to manage parties' discipline which can be done by various incentives and control mechanism. Parties should supervise their legislator and make sure they obeyed parties' disciplines. They also had to control the election of parliament leadership and its supporting tools, and distribute parliament resources to legislator.

Third, the parties' function is implementing the policy goal. In the government, political parties are the central actors who determine the output of government policies. Normally, the implementation of this function is formed by the transformation of parties' manifesto and promise in their previous campaign. There should be a consistency between parties' manifesto or platform and promise of campaign with the output policies. Fourth, organizing disagreement and opposition This function is performed by parties' who do not participate in the executives. Opposition parties form political block outside the executive. Hopefully, the opposition parties are able to attract voter in the next election.

Fifth, the function is ensuring the responsibility of government. The existence of opposition parties tell us to whom this responsibility of a government should be burdened i.e. to the ruling party. The ruling party is responsible for the government various actions. This mechanism makes the voters to give their credits or punishment easier to the government. If they are satisfied with the current government's work, they will give their credits. Otherwise if they feel unsatisfied with the government, they will give their vote to the opposition parties.

Sixth, the control through government administration. This function is attached to the party's role in controlling bureaucracy. This role is implemented by the participation of political parties to select an amount of individual for various political positions which has been agreed before.

At last, the parties' functions are correlated with their abilities to strengthen government stability, which directly correlated to democracy stability. In this framework, the parties' function to strengthen government stability and democracy can be done by keeping an eye to parties' stability. The unity of political parties should have been maintained to strengthen the government stability.

The fifth function indicates that the ruling party is responsible for various actions taken by the government. This action is manifested by watching how the elected regional head translates the political party programs into the government programs.

If individuals have agreed to all the issues of the party in general, they will choose the party without regard to issues other parties. Issues can also change alignments of someone in the party - a person can move from one party to another party since they are able to compare the issues which had been presented better by the other party (Niemi and Weisberg, 1984: 90).

In addition to finding a political choice for the love of the party and the party's ability to develop the issues will greatly affect the choice. Each description, the proclamation of a party by the mass media, will be able to 
shape public opinion to the parties concerned, thus besides being known as his/her name, it is also known for issue or program stated and done.

Furthermore, the party will convert the interests in society into a program or party issues offered through the campaign. After holding the reins of government, the party is obliged to make policies based on programs that they have already offered.

The parties will then transform it into a wide range of political issues and preparing a number of policy alternatives based on the general principles which form the basis of each party. That is how political parties will summarize a variety of packages into a coherent policy and loose - a process which provides a choice for voters in the election. Political parties is forming a government but can also act as an opposition in the legislature. They can occupy high echelons in the bureaucracy. Thus, political parties play a crucial role in decision making and implementation. (Klinaeman, et al., 2000: 9).

Parties are able to translate their program into public policy, demonstrating that the party understands its function to articulate and aggregate interests. When a policy of winners successfully realized, then the implementation of public policies implemented in a democratic atmosphere.

As quoted by Santoso (2010: 4-5) from Budiman, that public policy is the pulse of the governmental process. In the policy, the state power meet sovereignty, which in democratic norms are held by people or society. Because the nation-state regime that is currently dominant, only countries which have the legitimacy are able to make a public policy. In the context of democracy, the most basic questions about a policy is, "how far the government's policy 'linked' with the public will of its citizens?

The use of democratic rule would give effects to democratic public policy. democratic public policies will have the following advantages:

Easy to be implemented, because political support of the chosen policy was strong and make it easier for the implementation of policy since few parties will against it. Thus, the process of implementation will go well because there is less disturbance (Wahab, 2008)Will have a strong basis of legitimacy. The democracy in public policy raise the sense of belonging to all sections of the society over the policy. The policy was able to accommodate all interests and preferences in society. (Tim Penyusun Demokrasi, 2006: 165-166).

Policies made by the government that wins the election, so there was a possibility that the policy-making is intertwined with various interests. It has become the realm of power-chasing to affect each other and exert pressure on the parties. So it is not a surprise if Carl Friedrich defines policies as an action that leads to the goal proposed by a person, group, or government in the particular environment in connection with certain constraints while seeking opportunities to achieve certain goals. (Indiahono, 2009: 18)

Governmental functions basically cover the function of regulatory empowerment and development. From a regulatory function, the government have to process the policy and ensured it will be approved by legislature. Thus, the government requires trust of the public to ensure that their actions were very useful for society. The actions of the government are implemented for the sake of empowerment and development function. All such measures may become a study of scientists who are interested in policy studies. Government action is something empirical studied with aspects that are theoretical, so that the synergy between the "arena" empirical and arena "theoretical" occurred to develop policies as a dynamic science. Policy can be firstly studied from its formulation to until the evaluation of administrative and political viewpoints. From such standpoint, it can be seen whether the government makes policy by accommodating people or voters. The involvement of people in decision-making will bring researchers in the analysis of whether a government is democratic or not. The description is summarized by Nelson as follows:

To perform the function of government, public policy is divided into four areas: an interest in the patterns of political system thoroughly along with the process, a belief that the consequence of its actions is important, a struggle to produce knowledge theoretically and empirically useful, and countermeasures issues of democracy. (Nelson, 1996: 552).

The linkage between the policy and politics can be viewed on Bauer opinion, which is cited by Wahab:

The concept of public policy making by Raymond Bauer, writing the study of policy formation, positioned public policymaking as "the process of transformation 
which turn political inputs into political outputs" (Wahab, 2008: 53-54).

Thus, public policy which is viewed from democracy context, if it made as a political output, it should be formed based on feedback throughout a wide range of interests. Political parties which are metamorphosed themselves into executive power, as regents, and legislators should be able to translate people interest into policies. In terms of implementation, the policy becomes alienated with public life, because it has been enacted to accommodate the public interest.

The products of public policy which is also the first form of public policy is the legislation that had codified formally and legally (Nugroho, 2008: 61-62) in Indonesia include: (a) The Constitution of the Republic of Indonesia Year 1945 (UUD 1945), (b) Law / Government Regulation in Lieu of Law, (c) Government regulations, (d) Presidential decree, and (d) Local Government Regulation

Each regulation from the national level down to village level is a public policy. Public officials apparently are paid by public money through tax and other state revenues, and therefore, legally formally accountable to the public.

Thus, a series of public policy can simply be grouped into three, namely: (1) Public policy macro or general, or fundamental, that is the five rules that have been mentioned above; (2) Public policy that is messo or medium, or explanatory execution. This policy can be shaped regulation, Circular Letter of the Minister, the Governor Regulation, Regulation Regent and Mayor Regulation. Discretion may also form a Joint Decree or inter-ministerial decree, governors and regents or mayors; (3) Public policy is microeconomic policies that govern the execution or implementation of policies on it. Shape its policies are regulations issued by public authorities under ministers, governors, regents and mayors.

Nugroho further states, the shape of public policy is codified in general, but observed that the oral statements of public officials are also one form of public policy. Thus, the second form of public policy is the statement public officials (Nugroho, 2008: 63).

\section{Result and Discussion}

According to Nugroho (2009), mission is raison d'etre or axiological aspect why an organization should be formulated. Thus, mission determines "where the organization should go." Mission is attached to organization, and will be unchangeable during its existence, except there is an alteration or reformation within. Whether mission is attached on the individuals whom conduct the organization. Each leader should clearly determine his/ her direction in order to maintains the organization. In reality, vision is derivate into several missions, both vision and mission shifted dynamically relied on whom win the election. Rancier stated that mission and vision can only be executed in a favorable political situation. (Widiyanti, in MIMBAR Journal, 2017: 01).

After winning the Pilkada in 2010, it is time for Golkar in Bandung Regency implement its campaign promise or vision of its mission. Vision- mission are very possible to be implemented, since Golkar hold favorable political situation for their candidates, Dadang Naser with his deputy Deden Rukman Rumaji. The supporting political situation is the number of members on Local Representative Council/ DPRD of Bandung Regency in period of 2009-2014 which seated 9 people (republika.co.id, 2009 and the title Ketua dan Wakil Ketua DPRD Kabupaten Bandung Dilantik) as second position after Democrat Party, period 20142019 as 12 people (first order) is listed from Golkar and it has always won the elections since 2005 (bandungaktual.com: 2014 and the title Daftar Anggota DPRD Kabupaten Bandung Hasil Pemilu 2014).

When Golkar became the winner of the 2010 election, it executed its governmental fusion, especially in terms of policy implementation. Implementation of this function is formed through transformation of campaign promises into policies. The linearity between the campaign promise and the policy begins by generate vision to several missions. The vision of Bandung Regency (2011-2015) is: "Achieving WellDeveloped Bandung Regency, Independent and Competitive, through Good Governance and Village Development, based on Religious, Cultural, and Eco-Friendly Foundation", this vision is then further delegated into the mission as below:(1) Strengthening Bureaucracy Reforms; (2) Increasing the participation of the Private Sector and Civil Society in Development; (3) Improving the Quality of Human Resources; (4) Improving Empowerment Community Economy and Regional Competitiveness; (5) Improving the 
availability and quality of infrastructure, as well as integration of city space utilization; (6) Strengthening Rural Development; (7) Strengthening Social piety grounded in faith and Taqwa; (8) Explore, Develop and Preserving Culture Sunda and Other Local Wisdom; (9) Strengthen Balance Recovery Environment and Sustainable Development;

Vision and mission have very different meaning, but in the implementation, these two words cannot be separated, since the mission is a derivative of the vision, or vision has full coverage of all missions. Thus, carrying out the mission also means carrying out the vision, so it is not surprising that the vision and mission are inseparable.

The Regent mission subsequently translated into more technical by Bapedda Bandung Regency for further implementation in SKPD level. The similar context is also mentioned Chief of Bapedda in Bandung Regency, Ernawan Mustika:

\begin{abstract}
"The task of Bappeda related to the vision and mission of the Regent, every vision and mission translate into more technical language to be easily understood by SKPDs related, so then the implementation of the vision and mission can be carried out effectively and efficiently. Effective in performance, and efficient in the budget. Of course, from there, we always coordinate with existing SKPDs.
\end{abstract}

It also applies for the body that will accompany the village administration in carrying out development approved by the Community Empowerment and Village Governance Agency (BPMPD). The translation process through vision and mission interpretation of Regent became the authority and main focus of BPMPD, such as: giving assistance to the Regent mission, to achieve good governance through establishing rural development. Each SKPD including BPMPD serves to assist the Regent in achieving its mission objectives. Vision, mission and programs in each SKPD must be aligned with the Regents' mission. In addition, Regent's mission is not only translated by all SKPD, but also by the Village's Chief who will participate in their own election. For example, Village Chief of Cileunyi Kulon who derivates the Regent' mission into a vision during his tenure.

The linearity of Golkar program with the policies embodied in the sixth mission above is the main focus for researchers when looking at public policy products related to the mission. The sixth mission were out of the attention of researchers when analyzed product of public policies related to the mission. The survey results revealed that there are two regulations that are directly related to the program BPMPD namely the Regional Regulation No. 10 of 2011 on Irrigation and Regional Regulation No. 11 Year 2014 on the Management of Assets village. As for declaring, all three are consistent with this program. It means, to carry out the vision and mission of rural development, Bandung regency government issued public policy as much as 9 pieces at the macro level, and 3 are messo. But, BPMPD do not implement policies and community empowerment rural development and instead the agency simply provide recommendations on the amount of the amount of funds received by the village which is based on the analysis. This recommendation is then given to the financial DPPK. The funding department is take the responsibility to provide village funds transfer to an account via the village. The village fund disbursement scheme is as follows:

Send Proposal to RKPDes and APBDes $\rightarrow$ verification in Kecamatan $\rightarrow$ Being Analyzed by BPMPD $\rightarrow$ Recommendation from BPMPD to DPPK $\rightarrow$ transferred into Village Account

The main principle is the planning program by the village which is manifested in RKPD and APBD must be appropriate and linear with the vision and mission of Bandung Regency.

In BPMPD Strategic Plan (2010-2015), stated that there is a vision and mission related to the duties and functions of BPMPD namely, and in point helped Regent to achieve good Governance through Strengthening Rural Development. As for the strategy to be implemented by the Regent of Bandung, namely: (1) to increase empowerment of rural institution, (2) Increasing the capacity and capability of the village administration, (3) Increased self-reliance and kegotongroyongan (help each other) in villagers, (4) Capacity building and community empowerment, (5) Strengthening microfinance institutions in the village, (6) Improved source revenue, (7) Improved participation of community organizations in smooth distribution, price stability and food access, (8) Development of non-rice food processing technology, (9) Development of production and availability of food, (10) Distribution and access to food, and (11) Management of demand and consumption of food.

Of the 11 strategies, the program directly implemented by BPMPD in the 
village are the number 2 , in the form of training and socialization shaped Bimtek (Technical Assistance) to village officials. The focus is the development of Human Resources in Rural apparatus for using and managing the village fund. After that, the use of village funds left entirely to the village. BPMPD also perform no oversight or audit because the task is carried out by the inspectorate directly. There are oddities in this case, declaring that their implementing legislation and regional organizations, specifically for rural development directly undertaken by the village. In other words, the macro policy directly applied at the micro level, not via translation through messo policy.

The main obstacle in the construction and development of villages by BPMPD is human resources. For the direct program, they do is to provide training and socialization in Bimtek forms to village officials. However, other obstacles often emerged to the elected village through village elections (Pilkades), replace almost the entire apparatus entirely. Thus, those who have been given training cannot apply the knowledge they've gained from training and socialization conducted by BPMPD.

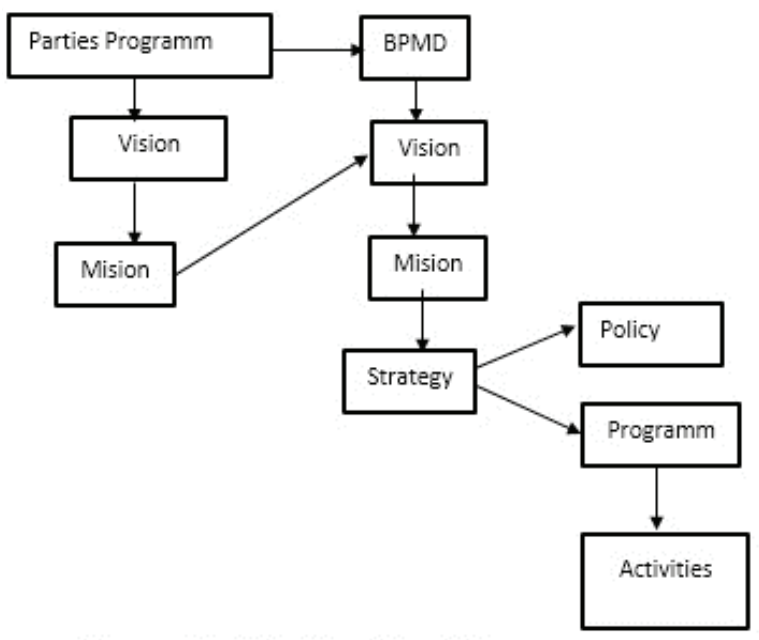

Sources: Adapted by Researchers, 2016

Figure 1

Consistency Models of Between Political Party Programs with Public

To observe the consistency between the programs of political parties with public policy products, researchers can only look at the level of programs and activities. Public policy both macro and messo difficult to explore the consistency, Regulation issued is not necessarily followed by Perbup. But policies messo be Perbup Number 19 Year 2013 on Guidelines for Strengthening Rural Development Programme in Bandung regency, is the governing implementation of macro form policy Perda Number 9 of 2013 on the Budget of the Regency Bandung (Bandung District Gazette Year 2013, No. 9).

BPMPD only perform the vision and mission of the elected Regent which is contained in policy strategies and programs, then put them into the program activities. For more details can be seen in the figure 1 .

Among the programs that go to the village is the improvement Livable House (Rutilahu) that aim to reduce the housing conditions of the poor as defined in Regulation No. 10 Year 2008 on Poverty Reduction in Bandung regency. Until now, Bandung district still has 20,000 of its original 70,000 Rutilahu in 2009. Rutilahu funded derived from the budget Rutilahu of: (1) Department of Housing, Spatial Planning and Hygiene, (2) PNPM (National Community Empowerment Program, (3) Sabilulungan (gotong royong/ helping each other) made under the name of development programs of rural development, and (4) ADD (Village Fund Allocation)

Rutilahu is very beneficial for society, even though the amount of aid Rp.7.000.000 still considered insufficient, especially for homes that were severely damaged. It is also expected to be more evenly and help more people to get it. Physical development does not dominate rural development, but also to think about empowerment for farmers to have a job in the dry season. Development according to the geographical conditions, is hoped by residents living in the areas of agriculture who relying on the rainy season.

\section{Conclusions}

The consistency between Golkar program's in village development has been already presented by functional group at the electoral campaign with policy products in Bandung Regency. It can be observed in policy product which has been issued by Bandung Regent, such as: Local Regulation no 10/2011 concerning on Irrigation and Local Regulation no 11/2014 concerning on Village Asset Management. As for Perbub (Regulation which is issued by Regent) all three are consistent with the programs. It means, in order to execute village development mission, the local government of Bandung Regency issued nine macro public policies and three policies with 
messo characteristic.

\section{References}

Creswell, John W (2012). Research Design: Pendekatan Kualitatif, Kuantitatif, dan Mixed. Edisi Ketiga. (Penerjemah: Achmad Fawaid). Yogyakarta: Pustaka Pelajar.

Daftar Anggota DPRD Kabupaten Bandung Hasil Pemilu 2014 (2014, April 26), retrieved from http://www. bandungaktual.com/2014/04/daftaranggota-dprd-kabupaten-bandung-html

Denzin, Norman K and Yvona S. Lincoln (2011). Disiplin dan Praktek Penelitian Kualitatif, dalam Denzin, Norman K dan Yvona S. Lincoln (Ed). The Sage Handbook of Qualitative Research. Edisi Ketiga. (Penerjemah: Daryatno). Yogyakarta: Pustaka Pelajar.

Hikmat, Mahi M. (2014). Pemetaan Masalah dan Solusi Konflik Lokal dalam Pilkada Langsung di Indonesia. MIMBAR (Jurnal Sosial dan Pembangunan). Volume 30, No. 1.

Indiahono, Dwiyanto (2009), Kebijakan Publik : Berbasis Dynamic Policy Analysis, Yogyakarta: Gava Media.

Ketua dan Wakil Ketua DPRD Kabupaten Bandung Dilantik, (2009, October 3), retrieved from http://www. republika. co.id/berita/shortlink/79525.

Klinaemann, dkk. (2000). Partai, Kebijakan \& Demokrasi (Penerjemah Sigit Jatmika), Yogyakarta : Pustaka Pelajar

Marshall, Catherine and Gretchen B. Rossman. (1995). Designing Qualitative Research (Second Edition). California: Sage Publication Inc.

Nelson, Barbara J,. Public Policy and Administration, dalam Robert E. Goodin dan Hans Dieter Klingemann (ed). (1996). A New Handbook of Political Science,
Oxford University Press Inc, New York.

Niemi, G. Richard dan Herbert F. Weisberg (1984), Controversies In Voting Behavior, Congressional Quarterly Inc, Washington. Nugroho, Riant. (2008). Public Policy. Jakarta: PT. Gramedia.

Pamungkas, Sigit(2011). Partai Politik: Teori dan Praktik di Indonesia. Yogyakarta: Institute for Democracy and Welfarism.

Powell, G. Bingham Jr. Consequences of Election, dalam LeDuc, Lawrence,et.all (eds). (2010). Comparing Democracies 3: Election and Voting in The 21st Century. London: Sage Publication

Pratikno. Political Parties in Pilkada: Some Problems for Democratic Consolidation, dalam Erb, Maribeth dan Priyambudi Sulistiyanto (ed) (2009). Deepening Democracy in Indonesia? Direct election for Local Leaders (Pilkada). Singapore: ISEAS Publishing.

Putra, Fadillah (2003). Partai Politik dan Kebijakan Publik: Analisis Terhadap Kongruensi Janji Politik Partai dengan Realisasi Produk Kebijakan Publik Di Indonesia 199-2003. Yogyakarta : Pustaka Pelajar.

Santoso, Purwo (2010). Modul Pembelajaran Analisis Kebijakan Publik. Yogyakarta: PolGov.

Sevilla, dkk (1993). Pengantar Metode Penelitian. Jakarta: UI Press

Tim Penyusun Demokrasi (2006). Reformasi Birokrasi dan Demokratisasi Kebijakan Publik. Malang: Averroes Press.

Wahab, Solichin Abdul (2008), Pengantar Analisis Kebijakan Publik, Malang: UMM Press.

Widiyanti, Diya Sri. (2017). Multicultural Politics in Governor Candidat of DKI Jakarta 2017 in Tempo.co. MIMBAR (Jurnal Sosial dan Pembangunan). Volume 33, No. 1 